\title{
PENGARUH PEMBERIAN TEKNIK RELAKSASI BENSON TERHADAP INTENSITAS NYERI PASIEN POST SECTIO CAESAREA DI RS PKU MUHAMMADIYAH CEPU
}

\author{
Warsono $^{(1)}$, \\ Faradisa Yuanita Fahmi ${ }^{(2)}$ \\ Galuh Iriantono ${ }^{(3)}$
}

1. Dosen Keperawatan Medikal Bedah Universitas Muhammadiyah Semarang, sony_nita12@yahoo.co.id

2. Dosen Keperawatan Medikal Bedah STIKES Muhammadiyah Kendal, yuanita0fara@gmail.com

3. Perawat RS PKU Muhammadiyah Kota Cepu, galuhiriantono@gmail.com

Corresponding Author: Warsono

\begin{abstract}
Abstrak
Sectio Caesarea memiliki efek samping diantaranya pada hari pertama pasca persalinan akan menimbulkan rasa nyeri yang hebat pada daerah insisi jaringan perut dan dinding uterus yang keadaarnya berbeda. Salah satu penatalaksaan nyeri non farmakologi pada pasien post oprasi adalah terapi teknik relaksasi benson, metode relaksasi benson merupakan pengembangan metode relaksasi pernafasan dengan melibatkan faktor keyakinan pada diri pasien. Mengetahui efektifitas teknik relaksasi benson terhadap intensitas nyeri pada Ibu hamil post section caesarea di Ruang Wijaya Kusuma PKU Muhammadiyah Cepu. Metode penelitian yang digunakan adalah quasi eksperimen dengan mengunakan rancangan pra-pasca pemberian terapi (one-grup pre test - post test design). Populasi Semua ibu hamil dengan post section caesarea di Ruang Wijaya Kusuma pada bulan Februari - Maret 2019, Sempel Penelitian sebayak 30 responden dengan mengunakan teknik accidental sampling, Analisa data dengan mengunakan uji Wilcoxon. Hasil uji Wilcoxon $p$ value $\leq 0.05$ artinya ada pengaruh penurunan intensitas nyeri setelah diberikan teknik relaksasi benson Kesimpulan menunjukkan ada pengaruh yang signifikan pada pemberian teknik relaksasi benson terhadap penurunan intensitas nyeri pasien post section caesarea. Sebagai saran Perawat sebaiknya menerapkan terapi non farmakologi teknik relaksi benson kepada pasien post section caesarea dan dijadikan SPO di rumah sakit dalam manajemen nyeri.
\end{abstract}

Kata Kunci : Section Caesarea, Relaksasi Benson, Nyeri

\section{PENDAHULUAN}

Sectio Caesarea merupakan salah satu tindakan medis dimana dilakukan suatu pembedahan guna melahirkan anak lewat insisi pada dinding abdomen dan uterus. (Oxom \& Forte, 2010). Permintaan ibu hamil untuk melakukan persalinan secara Sectio Caesarea mengalami kecenderungan peningkatan dari waktu ke waktu. Angka Sectio Caesarea terus meningkat dari 
Jurnal IImu Keperawatan Medial Bedah 2 (1), Mei 2019, 1-54

ISSN 2338-2058 (print), ISSN 2621-2986 (online)

insidensi 3 hingga 4 persen pada 15 tahun yang lampau, dan terjadi peningkatan 10 hingga 15 persen pada waktu sekarang.

Peningkatan tersebut dapat terjadi karena berbagai alasan seperti, pembedahan menjadi lebih aman untuk ibu, dan juga jumlah bayi yang cedera akibat partus lama dan pembedahan traumatic vagina menjadi berkurang. Perhatian terhadap kualitas dan pengembangan intelektual pada bayi telah memperluas indikasi Sectio Caesarea. Penyebab meningkatnya angka kejadian persalinan secara Sectio Caesarea juga tidak lepas dari perluasan indikasi yang dilakukan Sectio Caesarea dan kemajuan dalam teknik operasi dan anesthesia serta obat obat antibiotika (Oxom \& Forte, 2010).

Jumlah pasien Sectio Caesarea diIndonesia, terutama rumah sakit pemerintah adalah $20-25 \%$ dari total persalinan, sedangkan di rumah sakit swata jumlahnya lebih tinggi yaitu sekitar $30-80 \%$ dari total jumlah persalinan. Hasil penelitian ini sangat tinggi di bandingkan dengan anjuran departemen Kesehatan bahwa persalinan dengan Sectio Caesarea, seyogyanya tidak lebih dari 20\%. Studi pendahuluan yang dilakukan di RS PKU Muhammadiyah Cepu didapatkan data bahwa jumlah persalinan Sectio Caesarea adalah 32\% dari 100\% persalinan yang dilakukan (Rekam Medis, 2017).

Sectio Caesarea memiliki efek samping antara lain beberapa hari pertama pasca persalinan akan menimbulkan rasa nyeri yang hebat pada daerah insisi, disebabkan oleh robeknya jaringan pada dinding perut dan dinding uterus yang kadarnya berbeda - beda pada setiap ibu. Nyeri pada klien dengan Sectio Caesarea diakibatkan dari rahim yang sering berkontraksi karena masih dalam proses kembali ke bentuk semula dan juga rasa nyeri yang muncul dari daerah insisi operasi. Hampir semua pasien post oprasi sectio saesarea di RS PKU Muhammadiyah Cepu mengalami nyeri yang berbeda-beda tingkat dan intensitasnya, managemnt nyeri biasa diberikan dengan farmakologi / analgesik (Salawati, 2013).

Penanganan nyeri dilakukan secara farmakologi dan non-farmakologi dengan tujuan untuk mengobati nyeri tersebut dengan cara menghilangkan gejala yang muncul. Pasien masih merasa nyeri dan tidak mampu beradaptasi dengan nyeri yang dirasakan apabila efek dari analgetik hilang sehingga dibutuhkan terapi non-farmakologis (Sujatmiko, 2013). Teknik relaksasi nafas dalam, terapi musik, terapi placebo, relaksasi Benson dengan aromaterapi dan terapi Benson merupakan terapi non-farmakologi yang telah terbukti mampu menurunkan skala nyeri pasien post 
Jurnal IImu Keperawatan Medial Bedah 2 (1), Mei 2019, 1-54

ISSN 2338-2058 (print), ISSN 2621-2986 (online)

SC karena klien menjadi relax dan dapat beradaptasi dengan nyerinya (Irmawati \& Ratilasari, 2013; Lestari, 2011; Lukman, 2014; Patasik, Tangka dan Rottie, 2013; Sujatmiko, 2013).

Salah satu penatalaksaan nyeri non farmakologi khususnya pada pasien post oprasi adalah teknik rileksasi, Menurut Benson (1975) relaksasi adalah suatu prosedur untuk membantu individu berhadapan pada situasi yang penuh stress, rasa nyeri, menghilangkan ketegangan otot dan dapat memperbaiki gangguan tidur. Jurf and Nirschl (1993) relaksasi adalah strategi kognitif yang memberikan kesembuhan secara fisik dan mental atau mengurangi nyeri sampai ambang nyeri (Benson \& proctor 2011).

Berdasarkan pada studi pendahuluan yang dilakukan di RS PKU Muhammadiyah Cepu, didapatkan informasi bahwa jumlah pasien operasi Sectio Caesarea pada bulan januari 2018 sampai desember 2018 sebanyak 591 pasien. Pasien maupun perawat menyatakan bahwa belum ada tindakan spesifik oleh perawat diruangan untuk menstabilkan nyeri klien, terutama pada pasien dengan skala nyeri dibawah 7 atau dibawah nyeri berat. dengan terapi non farmakologi post Sectio Caesarea. Berdasarkan uraian tersebut maka peneliti tertarik untuk meneliti bagaimana pengaruh teknik rileksasi Benson terhadap intensitas nyeri pasien post section caesarea di Ruang Wijaya Kusuma RS PKU Muhamammadiyah Cepu.

\section{METODE PENELITIAN}

Jenis Penelitian yang dilakukan ini merupakan penelitian Quasi-eksperimen dengan menggunakan bentuk rancangan Pra - Pasca test dalam satu kelompok (One - grup pre test - post test design). Jenis penelitian yang digunakan adalah eksperimental semu atau quasi eksperimen. Penelitian ini bertujuan membandingkan intensitas nyeri pasien pasca operasi caesarea sebelum dan sesudah diberikan teknik rileksasi Benson.

Populasi dalam penelitian ini adalah pasien post Sectio Caesarea yang di rawat di Ruang Wijaya Kusuma RS PKU Muhammadiyah Cepu dengan rata-rata pasien sebanyak 30 perbulan. Sampel dalam penelitian ini adalah pasien dengan post Sectio Caesarea yang dirawat di Ruang Wijaya Kusuma RS PKU Muhammadiyah Cepu pada bulan Februari - Maret 2019 dengan teknik pengambilan sampel accidental sampling dengan memperhatikan kriteria tertentu, yaitu: 1) Tingkat kesadaran komposmentis, dan mampu berkomunikasi verbal, 2) Mau menjadi responden dan berada di tempat saat penelitian dilakukan, 3) Pasien yang merasa 
nyeri post Sectio Caesarea dengan skala nyeri kurang dari 8 dan masih mengalami nyeri 6 jam setelah operasi, 4) Belum pernah punya pengalaman operasi sebelumnya.

Penelitian dilakukan di Rumah Sakit PKU Muhammadiyah Cepu pada bulan Maret 2019, pengumpulan data di awali dengan penjelasan tujuan dan prosedur penelitian serta sudah di informed consent. data yang ada dilembar observasi dianalisa secara univariat dan bivariat (uji Wilcoxon Match Pairet Test)

\section{HASIL DAN PEMBAHASAN}

Tabel 1

Karakteristik Responden Berdasarkan Umur di Ruang Wijaya Kusuma RS PKU Muhammadiyah Cepu, bulan April $2019(\mathrm{n}=30)$

\begin{tabular}{ccccc}
\hline Karakteristik & Min & Max & Mean & Standar deviasi \\
\hline Umur & 24 & 41 & 32,77 & 4.688 \\
\hline
\end{tabular}

Tabel 1 diketahui bahwa karakteristik responden berdasarkan umur didapatkan umur termuda 24 tahun, umur tertua 41 tahun, rata-rata umur 33 tahun, dan standar deviasi $(4,688)$.

\section{Tabel 2}

Distribusi Frekuensi Karakteristik Responden Berdasarkan Pekerjaan di di Ruang Wijaya Kusuma RS PKU Muhammadiyah Cepu, bulan April 2019 ( $\mathrm{n}=30$ )

\begin{tabular}{ccc}
\hline Pekerjaan & Frekuensi & Persentase (\%) \\
\hline Guru & 5 & 16,7 \\
IRT & 10 & 33.3 \\
PNS & 6 & 20.0 \\
Swasta & 9 & 30.0 \\
\hline Total & 30 & 100,0 \\
\hline
\end{tabular}

Tabel 2 menunjukkan bahwa karakteristik responden berdasarkan pekerjaan sebagian besar bekerja sebagai IRT sebanyak 10 responden (33.3\%), bekerja swasta sebanyak 9 responden (30,0\%), PNS sebanyak 6 responden (20,0\%), dan Guru sebayak 5 responden (16,7 \%).

Kasron / Pijat kaki efektif menurunkan foo oedema pada penderita ....... Page $\mathbf{4 7}$ of 54 
Tabel 3

Distribusi Frekuensi Karakteristik Responden Berdasarkan Riwayat Obstetri di Ruang Wijaya Kusuma RS PKU Muhammadiyah Cepu, bulan April $2019(\mathrm{n}=30)$

\begin{tabular}{lcr}
\hline Riwayat Obstetri & Frekuensi & Persentase (\%) \\
\hline Hamil Pertama & 5 & 16.7 \\
Hamil Kedua & 11 & 36,7 \\
Hamil Ketiga & 10 & 33.3 \\
Hamil Keempat & 3 & 10,0 \\
Hamil Kelima & 1 & 3,0 \\
\hline Total & 30 & 100,0 \\
\hline
\end{tabular}

Tabel 3 menunjukkan bahwa karakteristik responden berdasarkan riwayat obstetri sebagian besar hamil kedua sebanyak 11 responden (36.7\%), hamil ketiga sebanyak 10 responden (33,3\%), hamil pertama sebayak 5 responden (16,7\%) dan kehamilan kelima sebanyak 1 responden $(3,0 \%)$.

Tabel 4

Distribusi Frekuensi Karakteristik Responden Berdasarkan Usia Kehamilan di Ruang Wijaya Kusuma RS PKU Muhammadiyah Cepu, bulan April $2019(\mathrm{n}=30)$

\begin{tabular}{ccc}
\hline Riwayat Usia Kehamilan & Frekuensi & Persentase (\%) \\
\hline 33 Minggu & 1 & 3,3 \\
\hline 34 Minggu & 3 & 10.0 \\
\hline 35 Minggu & 1 & 3,3 \\
\hline 36 Minggu & 5 & 16,7 \\
37 Minggu & 4 & 13,3 \\
38 Minggu & 7 & 23,3 \\
39 Minggu & 9 & 30,0 \\
\hline Total & 30 & 100,0
\end{tabular}

Karakteritik responden berdasarkan usia kehamian, rata-rata terbayak usia kehamilan responden adalah usia kehamilan 39 minggu sebanyak 9 responden (30,0\%), di ikuti 38 minggu sebayak 7 responden $(23,3 \%)$ yang paling sedikit usia kehamilan 33 minggu dan 35 minggu sebayak 1 responden $(3.3 \%)$.

Tabel 5 
Jurnal IImu Keperawatan Medial Bedah 2 (1), Mei 2019, 1-54

ISSN 2338-2058 (print), ISSN 2621-2986 (online)

Distribusi Frekuensi Skala Nyeri Pasien Post Sectio Caesarea Sebelum dan Sesudah Diberikan Tindakan Rileksasi Benson di Ruang Wijaya Kusuma RS PKU Muhammadiyah Cepu, bulan April $2019(\mathrm{n}=30)$

\begin{tabular}{lcccc}
\hline \multicolumn{1}{c}{ Karakteristik } & Min & Max & Mean & Standar deviasi \\
\hline Skala nyeri sebelum relaksasi Benson & 5 & 7 & 6.63 & 0,615 \\
\hline Skala nyeri setelah relaksasi Benson & 3 & 6 & 4.20 & 0,761 \\
\hline
\end{tabular}

Tabel 5 menunjukkan bahwa sebelum pemberian relaksasi Benson rata-rata intensitas skala nyeri 6,63, Maxsimal skala nyeri 7, Minimal skala nyeri 5 dengan standar deviasi 0,615 dan pada responden setelah pemberian relaksasi Benson rata-rata intensitas skala nyeri 4,20, Maxsimal skala nyeri 6, Minimal skala nyeri 3 dengan standar deviasi 0,761 .

Tabel 6

Distribusi Frekuensi Kategori Nyeri Pasien Post Sectio Caesarea Sebelum dan Sesudah Diberikan Teknik Releksasi Benson di Ruang Wijaya Kusuma RS PKU Muhammadiyah Cepu, bulan April $2019(\mathrm{n}=30)$

\begin{tabular}{lcccr}
\hline \multirow{2}{*}{ Kategori Nyeri } & \multicolumn{2}{c}{ Sebelum Perlakuan } & \multicolumn{2}{c}{ Sesudah Perlakuan } \\
\cline { 2 - 5 } & $\begin{array}{c}\text { Frekuensi } \\
(\mathbf{F})\end{array}$ & $\begin{array}{c}\text { Persentase } \\
\mathbf{( \% )}\end{array}$ & $\begin{array}{c}\text { Frekuensi } \\
(\mathbf{F})\end{array}$ & Persentase (\%) \\
\hline Tidak nyeri & 0 & 0,0 & 0 & 0,0 \\
Nyeri ringan & 0 & 0,0 & 5 & 16,7 \\
Nyeri sedang & 9 & 30.0 & 25 & 83,3 \\
Nyeri berat terkontrol & 21 & 70,0 & 0 & 0.0 \\
Nyeri berat tak terkontrol & 0 & 0,0 & 0 & 0,0 \\
\hline Jumlah & $\mathbf{3 0}$ & $\mathbf{1 0 0 , 0}$ & $\mathbf{3 0}$ & $\mathbf{1 0 0 , 0}$ \\
\hline
\end{tabular}

Tabel 5 menunjukkan bahwa sebelum pemberian relaksasi Benson sebagian besar intensitas nyeri berat terkontrol sebanyak 21 responden $(70,0 \%)$, nyeri sedang 9 responden $(30.0 \%)$ dan sesudah diberikan relaksasi Benson 25 responden (83,3\%) kategori nyeri sedang dan 5 responden (16,7\%) kategori nyeri ringan. 
Jurnal IImu Keperawatan Medial Bedah 2 (1), Mei 2019, 1-54

ISSN 2338-2058 (print), ISSN 2621-2986 (online)

Tabel 7

Pengaruh Pemberian Relaksasi Benson Terhadap Intensitas Nyeri Pada Pasien Post Sectio Caesarea di Ruang Wijaya Kusuma RS PKU Muhammadiyah Cepu, bulan April 2019 (n=30)

\begin{tabular}{lcccc}
\hline Variabel & Hasil & $\mathrm{N}$ & Mean Rank & P Value \\
\hline Intensitas nyeri sebelum diberikan relaksasi & Negatif & 28 & 14,50 & 0,000 \\
Benson - Intensitas nyeri sesudah diberikan & Positif & 0 & 0,00 & \\
relaksasi Benson & Ties & 2 & & \\
\hline & Total & 30 & \\
\hline
\end{tabular}

Tabel 7 menunjukkan 28 responden mengalami penurunan intensitas nyeri sesudah diberikan relaksasi Benson, ada 2 responden yang intensitas nyerinya sama dan tidak ada responden yang intensitas nyerinya meningkat. Hasil uji Wilcoxon match pair test didapatkan nilai $\mathrm{p}$ value $=0,000$ maka Ho ditolak dan Ha diterima artinya ada pengaruh yang bermakna pemberian Relaksasi Benson terhadap intensitas nyeri pada pasien post Sectio Caesarea Ruang Wijaya Kusuma RS PKU Muhammadiyah Cepu

\section{PEMBAHASAN}

Hasil Penelitian yang di lakukan terhadap 30 responden post Sectio Caesarea di Ruang Wijaya Kusuma RS PKU Muhammadiyah Cepu dapat disimpulkan bahwasannya teknik rilksasi benson sangat efektif dalam menurunkan intensitas nyeri. Uji analisa Wilcoxon match pair test didapatkan $\mathrm{P}$ value $=0,000$ maka memang ada pengaruhnya pemberian teknik rilaksasi benson terhadap intensitas nyeri. Hasil ini sejalan dengan yang dilakukan oleh Afnijar (2018) pada pasien pasca section caesarea di RSUD Raja Ahmad Thabib dijumpai hasil analisis P-value untuk relaksasi benson $0,001<0,05$ maka Ho ditolak artinya ada pengaruh penurunan rasa nyeri pada pasien pasca section caesarea pada perlakuan relaksasi benson.

Relaksasi benson adalah suatu jenis terapi untuk penanganan kegiatan mental dan menjauhkan tubuh dan pikiran dari rangsangan luar untuk mempersiapkan tercapainya hubungan yang lebih dalam dengan pencipta, yang dapat dicapai dengan metode hypnosis, meditasi yoga, 
Jurnal IImu Keperawatan Medial Bedah 2 (1), Mei 2019, 1-54

ISSN 2338-2058 (print), ISSN 2621-2986 (online)

dan bentuk latihan-latihan yang ada hubungannya dengan penjajakan pikiran (Kasdu, 2003).

Relaksasi benson merupakan pengembangan metode respon relaksasi dengan melibatkan keyakinan pasien, mendapat menciptakan suatu lingkungan tenang sehingga dapat membantu pasien mencapai kondisi kesehatan dan kesejahteraan lebih tinggi (Purwanto, 2011). Relaksasi benson merupakan tehnik relaksasi yang digabungkan dengan keyakinan/keimanan yang dianut oleh pasien. Ungkapan yang dipakai dapat berupa nama tuhan atau kata-kata lain yang memiliki efek menenangkan bagi pasien yang membaca secara berulang-ulang (Benson \& Proctor, 2011).

Hasil penelitian terdapat dua responden setelah mendapatkan terapi intensitasnya masih sama / tidak mengalami penurunan, penyebabnya bisa karena respon persepsi nyeri dari masingmasing individu yang berbeda tergantung usia, lingkungan dan pengalam, seperti yang di ungkapkan oleh Syahriyani (2010), perbedaan tingkat nyeri yang dipersepsikan oleh pasien disebabkan oleh kemampuan sikap individu dalam merespon dan mempersepsikan nyeri yang dialami. Kemampuan mempersepsikan nyeri dipengaruhi oleh beberapa faktor dan berbeda diantara individu. Tidak semua orang terpajan terhadap stimulasi yang sama mengalami intensitas nyeri yang sama. Sensasi yang sangat nyeri bagi seorang mungkin hampir tidak terasa bagi orang lain. Riwayat kehamilan dari ke dua pasien adalah kehamilan yang pertama sehingga pasien belum punya pengalaman terhadap proses melahirkan maupun oprasi sectio caesarea. Seperti yang diungkapkan oleh Alimun (2010) Individu yang mempunyai pengalaman multipel dan berkepanjangan dengan nyeri akan lebih sedikit gelisah dan lebih toleran terhadap nyeri dibanding orang yang hanya mengalami sedikit pengalaman tersebut.

Cara pengobatan ini merupakan pembagian pengobatan spritual. Pada tehnik ini pengobatan sangat fleksibel dapat dilakukan dengan bimbingan mentor, bersama-sama atau sendiri. Tehnik ini merupakan upaya untuk memusatkan perhatian pada suatu fokus yang menyebut berulang-ulang 
Jurnal IImu Keperawatan Medial Bedah 2 (1), Mei 2019, 1-54

ISSN 2338-2058 (print), ISSN 2621-2986 (online)

kalimat ritual dan menghilangkan berbagai pikiran yang mengganggu. Tehnik pengobatan ini dapat dilakukan setengah jam 2 kali sehari (Sanjaya, J., 2015). Teknik Relaksasi Benson merupakan teknik latihan nafas. Dengan latihan nafas yang teratur dan dilakukan dengan benar, tubuh akan menjadi lebih rileks, menghilangkan ketegangan saat mengalami stress dan bebas dari ancaman. Perasaan rileks akan diteruskan ke hipotalamus untuk menghasilkan Corticotropin Releasing Factor (CRF). Selanjutnya CRF merangsang kelenjar pituitary untuk meningkatkan produksi Proopioidmelanocortin (POMC) sehingga produksi enkephalin oleh medulla adrenal meningkat. Kelenjar pituitary juga menghasilkan $\beta$ endorphin sebagai neurotransmitter yang mempengaruhi suasana hati menjadi rileks. Meningkatnya enkephalin dan $\beta$ endorphin kebutuhan tidur akan terpenuhi dan lansia akan merasa lebih rileks dan nyaman dalam tidurnya.

Berdasarkan dari konsep dasar relaksasi merupakan suatu keadaan rileks dimana seseorang dalam keadaan sadar namun rileks, tenang, istirahat pikiran, otot - otot rileks dan pernafasan dalam yang teratur. Keadaan ini menurunkan rangsangan dari luar terhadap formatio reticuler. Perangsangan pada nuklei reticuler non spesifik yang mengelilingi thalamus dan nuklei dalam yang difus sering mampu mencetuskan gelombang dalam sistem thalamokortikal. Dengan relaksasi maka proses pernafasan, ventilasi, difusi dan perfusi menjadi terkontrol. Adanya pemusatan fikiran maka impuls dari stresor negatif bisa dialihkan sehingga secara tidak langsung akan membantu dalam menjaga keseimbangan homeostasis tubuh melalui jalan HPA Axis, yang dapat merangsang produksi kortisol dalam batas normal. Kortisol yang normal akan menciptakan keseimbangan neurotransmitter tubuh yang bermuara pada keseimbangan homeotasisnya. (Guyton, 2008).

Pernafasan yang panjang dapat memberikan energi yang cukup, karena pada waktu menghembuskan nafas mengeluarkan karbondioksida (C02) dan saat menghirup nafas panjang 
Jurnal IImu Keperawatan Medial Bedah 2 (1), Mei 2019, 1-54

ISSN 2338-2058 (print), ISSN 2621-2986 (online)

mendapatkan oksigen $(\mathrm{O} 2)$ yang sangat diperlukan tubuh untuk membersihkan darah dan mencegah kerusakan jaringan otak akibat kekurangan oksigen (hipoksia) ( Yani, dkk, 2009; Davis, 1995). Pada waktu tarik nafas panjang otot-otot dinding perut (rektus abdominalis, transversus abdominalis, internal dan eksternal oblique) menekan iga bagian bawah ke arah belakang serta mendorong sekat diafragma ke atas dapat berakibat meninggikan tekanan intra abdominal, sehingga dapat merangsang aliran darah baik pada vena cava inferior maupun aorta abdominalis, mengakibatkan aliran darah (vaskularisasi) menjadi meningkat ke seluruh jaringan tubuh terutama organ - organ vital seperti otak. (Sudarsono, 1995).

Pemberian latihan teknik relaksasi benson sangat bernafaat pada semua pasien karna terapi rilaksasi benson tidak hanya membatu menurunkan intensitas nyeri tapi juga akan menjadikan pasien lebih rileks. Pemberian latihan secara teratur dan dibawah bimbingan seseorang belajar untuk rileks dan menurunkan reaksinya terhadap stres (Ahmed. S, Makama. J, dkk, 2014).

\section{KESIMPULAN}

Penelitian yang dilakukan di Ruang Wijaya Kusuma PKU Muhammadiyah Cepu terhadap 30 responden memiliki karakteristik yang berbeda-beda dari usia rata 32 tahun, pekerjaan sebagin besar ibu rumah tangga (IRT) sebesar 33,3\%, riwayat obstektik sebagin besar responden kehamilan ke dua sebesar 36,7 \% dan intensitas nyeri rata-rata 6,63 seblum dilakukan tindakan, serta intensitas nyeri setelah tindakan 4,20.

Rata - rata penurunan intensitas nyeri pada pasien post Sectio Caesarea 2,4. Aplikasi teknik relaksasi benson akan efektif jika di terapkan pada pasien dengan sekala nyeri maksimal 7 (kategori nyeri sedang). Hasil analisa bivariet penelitian yaitu $P$-value $=0,001$ dimana $p$-value $<0,05$, maka hal ini menunjukan bahwa ada perbedaan intensitas nyeri pre - post terapi, sehingga teknik relaksasi benson sangat efektif diterapkan pada pasien post Sectio Caesarea dalam menurunkan intensitas nyaeri dan sangat di anjurkan untuk di aplikasikan pada semua pasien yang mengalami gangguan psikologis agar bisa menjadikan lebih rileks dan bisa mengontrol kecemasan serta tingkat stres. 
Saran untuk rumah sakit sebaiknya teknik relaksasi benson jadikan SOP yang baku dan di sediakan lembar observasinya. Perawat sebaiknya menerapkan teknik relaksasi benson tidak hanya pada pasien post Sectio Caesarea tetapi bisa diterapkan pada pasien yang mengalami nyeri, kecemasan dan setres hospitalisasi. Bagi peneliti selanjutnya sebaiknya tidak hanya satu varibel nyeri bisa diapliksikan pada perubahan respon fisiologis tekanan darah saja, bisa melakukan peenelitiaan selanjutnya dengan meneliti respon fisisologi ibu hamil.

\section{DAFTAR PUSTAKA}

Alimul, A., (2010). Pengantar Kebutuhan Dasaar Aplikasi Konsep dan Proses Keperawatan. Jakarta: Salemba Medika.

Benson dan Proctor. (2011). Dasar-Dasar Respon Relaksasi: Bagaimana Menghubungkan Respon Relaksasi Dengan Keyakinan Pribadi Anda (Ahli Bahasa oleh Nurhasan. Bandung: Kaifah.

Berman, S., \& Kozier. (2009). Buku Ajar Praktik Keperawatan klinis Kozier. Jakarta: EGC.

Datak, Gad. (2008). Efektifitas Relaksasi Benson Terhadap Nyeri pada Pasca Bedah Pada Pasien Transurethal Resection of The Prostate. RSU Pusat Fatmawati . Jakarta: FIK UI.

Guyton, Arthur c \& Hall (2008). Buku Ajar Fisiologi Kedokteran. Jakarta: EGC.

Kasdu, Dini. (2003). Operasi Caesar Masalah dan Solusinya. Jakarta: Puspa Swara.

Lestari, R. (2011). Pengaruh Relaksasi Benson Terhadap Nyeri Pada Pasien Post Sectio Caesarea Di RSU PKU Muhammadiyah Bantul Yogyakarta. FKIK (Ilmu Keperawatan), 7.

Lukman. (2014).Pengaruh Teknik Relaksasi Nafas Dalam terhadap Intensitas Nyeri pada Pasien Post-operasi Sectio Caesaria Di Rumah Sakit Umum Daerah Prof. Dr. Hi. Aloei Saboe Kota Gorontalo. Diakses dari: http://eprints.ung.ac.id/3221/. pada tanggal: 19 September 2015.

Oxom dan Forte. (2010). Ilmu Kebidanan Patologi dan Fisiologi Persalinan, CV. Andi Offset, Yogyakarta.

Purwanto. (2011). Pengaruh Latihan Relaksasi Religius untuk Mengurangi Insomnia di Yogyakarta. Universitas Muhammadiyah Yogyakarta.

Salawati. (2013).Profil Sectio Caesarea di RRumah Sakit Umum Daerah DR. Zainal Abidin Banda Aceh Tahun 2011. Jurnal Kedokteran Syiah Kuala. 13(3).39-143.

Sanjaya, J. (2015). Terapi Benson. http://jefry-sanjayastikesmuhkusus.blogspot.co.id/2015/12/terapi-banson.html. Diakses pada 15 Oktober 2017.

Sujatmiko. (2014). Pengaruh Pemeberian Aroma Terapai Lavender Terhadap Tingkat Nyeri Pada Pasien Gastritis Di Ruang Dahlia RSUD Nganjuk. Stikes Satriya Bhakti Nganjuk. (6364)

Sahriyani. (2010). Penagruh Teknik Relaksasi Terhadap Penurunan Intensitas Nyeri Pada Pasien Post Op Apendiktomy. RSU TK II Pelamonia Makasar.

Wahyu, A. (2018). Efektifitas Relaksasi Benson Terhadap Penurunan Nyeri Pasien Pasca Sectio Caesarea. Jurnal Keperawatan Silampari (JKS) 2 (1) 236-251

Kasron / Pijat kaki efektif menurunkan foo oedema pada penderita ....... Page $\mathbf{5 4}$ of $\mathbf{5 4}$ 